\title{
Explaining the Economic Slowdown of 1979: A Supply and Demand Approach
}

\author{
KEITH M. CARLSON
}

$T_{\mathrm{H}}$ HE long-awaited slowdown in the U.S. economy finally occurred in 1979 . Whether it eventually will be labeled a recession, however, is still an open question. ${ }^{1}$

Whether the economy is in recession is, of course, a matter of concern for policymakers. More important for them, however, are the causes of the slowdown since the nature of these underlying causes determines the type of response that they must make to achieve the nation's economic goals.

This article analyzes the causes of the 1979 slowdown in economic activity with the use of a simple supply and demand framework. The analysis is kept simple to demonstrate that models of the economic system need not be large and complex in order to give a general picture of the forces that produce changes in output and the price level. The near-term economic outlook is then discussed within this framework. No specific forecasts are made, but, given certain assumptions about economic behavior, the implications of different policy scenarios are summarized.

\section{The Arithmetic of the Slowdown}

After expanding significantly in 1978, the pace of economic activity began to slow in early 1979 . In the first four months of the year, the economic indicators were difficult to interpret because of shocks to the economic system. ${ }^{2}$ Since spring, however, economic

1The National Bureau of Economic Research has not yet issued an official ruling on whether the current slowdown in the U.S. economy qualifies as a recession. Contraty to popular belief, the National Bureau does not make such a determination merely by looking at the course of constant dollar GNP. Many other economic time series are examined as part of that decision.

2First, there was the impact of severe weather in some parts of the country. Second, there were major work stoppages in early spring. And finally, energy prices stated to accelerate in the first quarter. developments indicate that more fundamental forces have been slowing the advance of the economy. Most measures of monetary and fiscal action, for example, moved in the direction of less stimulus in late 1978 and early 1979.

The progress of the economy in the first three quarters of 1979 is summarized in table 1. These figures provide background for the analytical section that follows. For comparison's sake, percent changes for 1978 and a previous part of the expansion are also summarized.

Income and sales - The top tier of numbers summarizes the movement of the economy in nominal terms, that is, without adjustment for changes in the price level. Nominal measures provide an indication of the thrust of monetary and fiscal actions on total spending in the economy. The most important of these measures, gross national product (GNP), slowed in the first three quarters of the year relative to 1978 . Personal income and retail sales also advanced more slowly, although retail sales showed substantial quarter-to-quarter variation.

Production and emplogment - Although nominal indicators are important in the interpretation of economic developments, real indicators must receive the major emphasis in assessing the course of economic activity. GNP (in 1972 prices) serves as the funda mental indicator of economic progress in the United States. This measure of the nation's output slowed markedly in the first quarter, declined in the second, and then increased moderately in the third quarter. Industrial production, which accounts for about 30 percent of GNP, serves as a sensitive indicator of output trends. It slowed to a 4 percent annual rate of increase in the first quarter, and changed little in the second and third quarters.

The course of production is the key to employment 


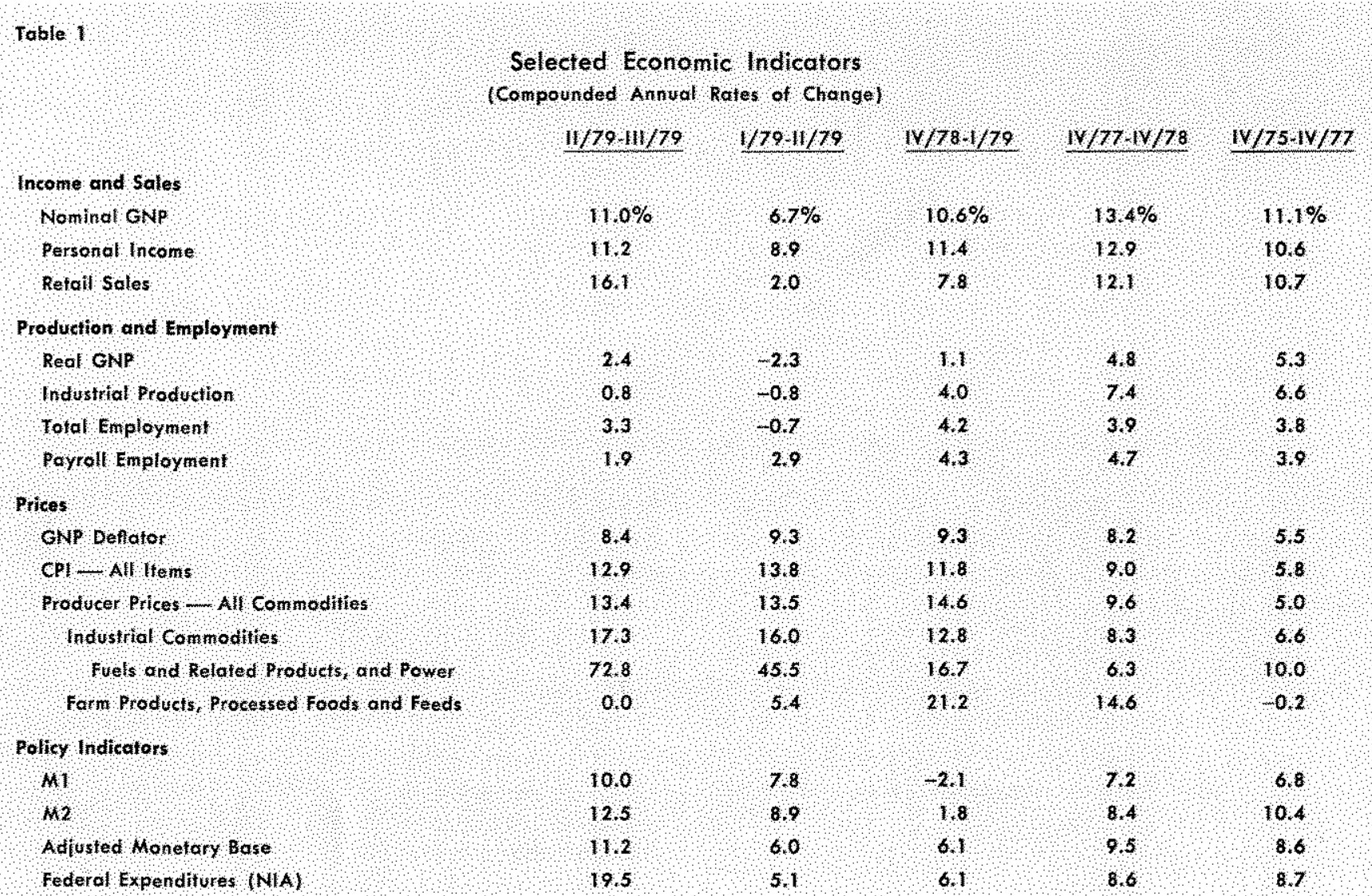

trends. Its effect on employment is lagged, however, since employers are reluctant to lay off workers until convinced the signs of economic slowdown are not transitory. In the first quarter of 1979 , for example, employment continued its rapid growth in the face of slowing production. Since the first quarter, however, employment growth has, on balance, moderated.

Prices - While major measures of price change accelerated in 1978, the pace stepped up further in 1979 . Accelerating prices in the face of slowing production and output is not without precedent, however, since prices reflect forces that build up over time and are not particularly sensitive to short-run movements in the pace of economic activity. ${ }^{3}$ Furthermore, the price level is subject to supply shocks, such as energy developments and agricultural conditions, which can dramatically affect prices for several months and mask the movement of the underlying trend in inflation. Two primary measures of these shock effects

$3_{\text {Geolfrey Moore discusses this point and finds evidence that }}$ economic slowdowns reduce the inflation rate. See Geoffrey H. Moore, "Will the Slowdown Reduce the Inflation Rate? Probably, Across The Board, The Conference Board Magazine (September I979) pp. 3-7. For a contrary view, see John A. Tatom, "Does the Stage of the Business Cycle Affect the Inflation Rate?" this Review (September 1978), pp. 7-15. are summarized in table 1 as "producer prices for fuels and related products, and power, and "farm products, processed foods and feeds." Energy prices rose at a very high rate in the first three quarters of 1979. Farm prices, on the other hand, vacillated in 1979 but, on balance, increased at about the same rate as overall prices.

Policy indicators - Finally, table 1 summarizes the movements of some major policy indicators. Interpretation of the monetary aggregates, the fundamental indicators of monetary policy, has been made difficult because of innovations in the financial industry. ${ }^{4}$ Yet, in perspective, the trends are quite clear. Monetary growth decelerated sharply in the first quarter, but rebounded vigorously in the second and third quarters. Federal expenditures, a summary measure of fiscal actions, showed moderate growth in the first two quarters of 1979 , then rose sharply. ${ }^{5}$

*For a discussion of these innovations, see "A Proposal for Redefining the Monetary Aggregates," Federal Reserve Bulletin (Jauuary 1979), pp. 13-42.

tThis pattern of slow growth for federal expenditures in the first half of the year followed by rapid growth in the second half has been oecurring since 1975. See this Bank's release, "Monetary Trends." 


\section{A Framework of Analysis}

The path of the economy in 1979 is quite clear a slowing of output growth and an acceleration of prices. A description of how the economy has moved, even when accompanied with a summary of the major policy indicators, however, is of little use to policymakers unless cast within a framework of economic analysis. Only with an understanding of the forces which produce the slowdown can policymakers make a proper choice of policy.

To assist in the explanation of the 1979 economic slowdown, a model of output and price level determination is presented. The general analytical ap-

$106 \mathrm{~s} 2$

Factors Infuenchg Aggregate Supply and Demand

Aggregate Supply

Techologled progress

Capiol siock

lobor lore

Nominol roge

Price of enengy

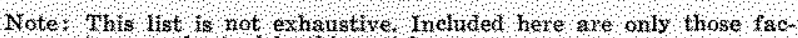
tors emphasted the thetele

proach is that output and the price level are determined by the intersection of aggregate supply and aggregate demand. The factors which enter into the determination of supply and demand represent a complex interaction of economic forces (table 2).

Aggregate demand - Figure 1 , drawn to depict the economy in the fourth quarter of 1978 , summarizes the model graphically. ${ }^{6}$ Aggregate demand for output (DD) is drawn as a function of the price level, with less output demanded at higher price levels.

The shape and position of the aggregate demand curve is a subject for empirical analysis. For purposes of this discussion, however, the demand curve is drawn so that the price level times the quantity of output (that is, nominal GNP) is constant, This follows from the assumption that the key determi nant of the demand for money is nominal GNP. Consequently, for a given stock of money, the de-

Data for the private business sector are used in the construction of all the figures. Private business sector ontput is defined as the market value of the goods and services produced by factors of production in the United States minus those goods and services attributable to (1) owner-ocomied dwellings, households, and nonprofit institutions, and (2) general government.

TThe aggregate demand curve is drawn as a rectangular hyperbola in figure I (and in all other figures), but appears limear because of the break in both axes.

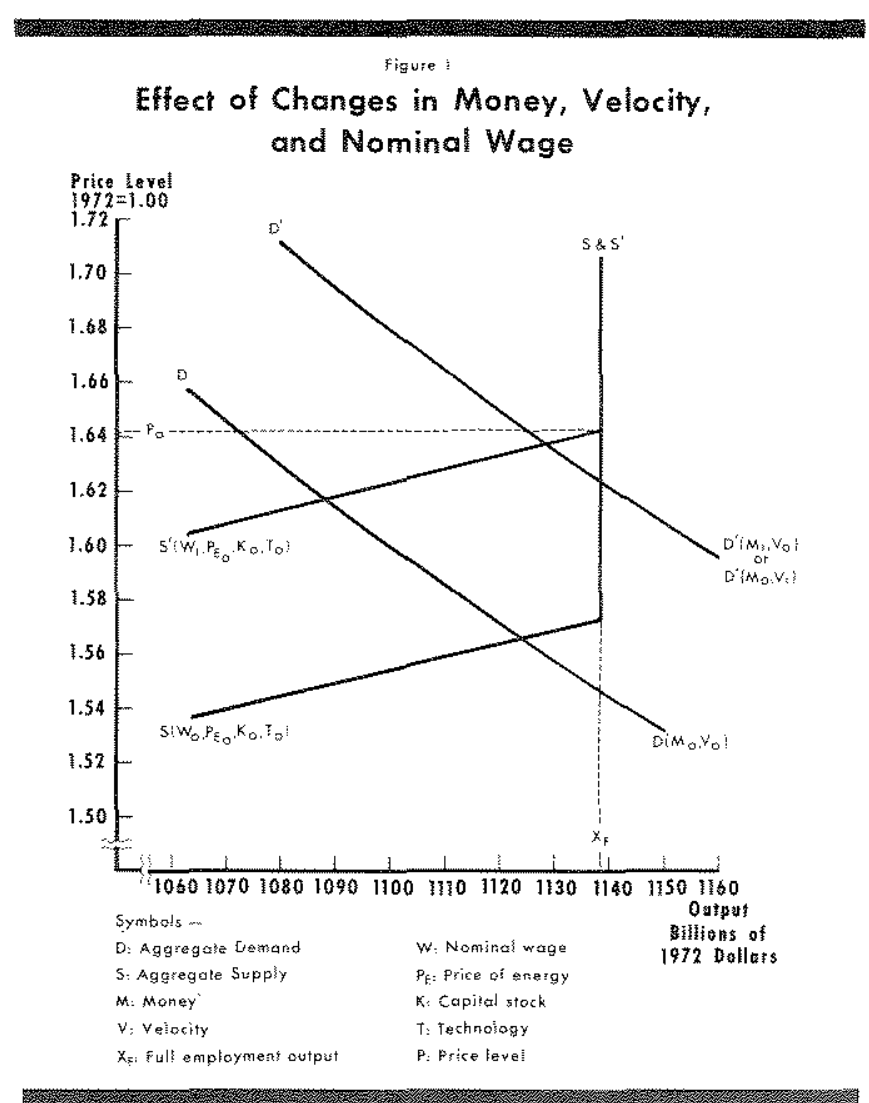

mand curve depicts those combinations of price level and output that equate the quantity of money demanded with a given quantity supplied. The quantity of money supplied is determined by monetary authorities, but the demand for money depends on the behavior of economic units. An alternative interpretation is to think of nominal GNP as determined by the quantity of money and its velocity of circulation.

To analyze the course of economic events, it is important to identify the factors that shift the demand curve since economic analysts are interested in how forces move the economy from one position to another through time. Empirical analysis has demonstrated that shifts in aggregate demand are systematically infuenced by changes in the quantity of money. ${ }^{8}$ A complete analysis, however, requires consideration of those factors affecting the demand for money (or velocity) over time. The effect of an increase in either the money stock or velocity by 5 percent is shown as a shift upward and to the right of the

\footnotetext{
SThe basic reference is Leonall C. Antersen and Jerry $L$. Jordan, "Monetary and Fiscal Actions: A Test of Their Relative Importaze in Econonic Stabilization," this Review (November 1968), pp. 11-24. For an tpdate and critique of this article, see Keith M. Carlson, "Does the St. Louis Equation Now Believe in Fiscal Policy?" this Reviete (February 1978), pp. $13-19$.
} 


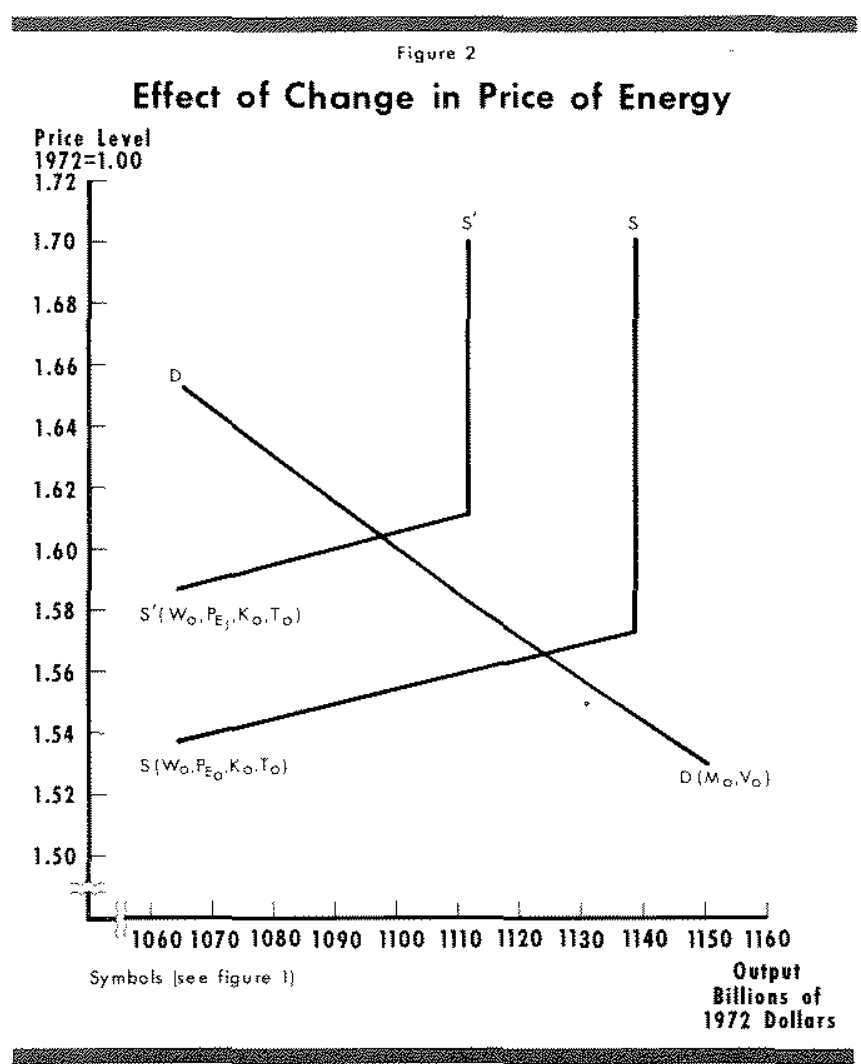

aggregate demand curve, from $\mathrm{DD}$ to $\mathrm{D}^{\prime} \mathrm{D}^{\prime}$ in figure 1. A larger stock of money (or a reduced demand for money, that is, an increase in velocity) requires a larger nominal GNP to equate the quantity of money supplied with the quantity demanded.

Aggregate supply - The demand curve, which represents equilibrium in the money market, is not sufficient to determine how nominal GNP is divided between prices and output. To complete the model, the supply side of the market must be specified. The aggregate supply curve represents the amount of output that producers are willing to supply at various price levels. This is significantly influenced by factors affecting the labor market, that is, by the supply and demand for labor. As with aggregate demand, it is important to identify those factors that determine the shape and position of the aggregate supply curve.

The aggregate supply curve in figure 1 slopes upward to the point where labor is "fully employed;" at that point, $X_{F}$, it becomes vertical. The amount producers are willing to supply at different price levels in the short run (a period short enough that the capital stock can be assumed fixed) depends on such factors as the amount of the capital stock, the level of technology, the size of the labor force, and the prices for two variable factors of production - labor and energy.
The upward-sloping portion of the supply curve reHlects the simplifying assumption that at output levels below full employment producers can hire any amount of labor that they want without affecting the nominal wage. The reason producers are willing to supply more output only at higher price levels, even if nominal wages are constant, is that the addition of more of a variable factor like labor to a set of fixed factors results in diminishing returns to the variable factor. To cover the higher cost per unit of extra product, the producer asks for a higher price. The vertical portion of the supply curve reflects the following assumption: attempts to expand output beyond levels commensurate with fully employed labor merely bid up the nominal prices of fully employed labor, capital, and energy.

Shifts in aggregate supply occur because of a change in any one or a combination of several factors. Changes in the capital stock and technology are instrumental in shifting aggregate supply over time, but these factors seldom change abruptly over short periods. The other two factors - the price of labor and the price of energy - can change dramatically in a short period of time. Movements in the price of labor will, of course, reflect productivity trends as well as past and expected price levels. The price of energy is determined by the interplay of supply and demand in world markets. ${ }^{9}$

Two aggregate supply curves are drawn in figure 1. ${ }^{\text {to }}$ SS represents supply conditions as they existed in the fourth quarter of 1978 . S'S' shows the effect of a nominal wage 5 percent higher than used in the construction of SS. At the higher nominal wage, less output will be produced at each price level below $P_{a}$. Once capacity output, $X_{F}$, is reached, output does not respond further to the price level because of the as sumption of fully employed labor. If aggregate demand is unchanged, the effect of the higher nom* inal wage will be temporary. The higher unemployment coupled with competition in the labor market will reduce the nominal wage toward its equilibrium level.

Of particular significance is the effect of higher energy prices. Figure 2 illustrates this effect. SS and

"For an analysis of the impact of energy prices on aggregate supply, see Robert H. Rasche ard John A. Tatom, "The Effects of the New Enety Regine on Economic Capacity. Production, and Prices," this Review (May 1977), pp, 2-12,

10'These supply curves are constructed using a Cobb-Donglas production as estimated by Rasche and Tatom. Imolicit in their construction is the assumption that a short-run equilibrium prevails in the labor market - given the nominal wage. 
DD are the same as in figure 1 , consistent with conditions prevailing in the fourth quarter of $1978 . S^{\prime} S^{\prime}$ in figure 2, however, reflects energy prices 30 percent higher than used in the construction of SS. The effect is similar to that for a higher nominal wage with one important difference - full-employment output is reduced by an increase in the price of energy. The reason for this is that the reduction in energy use as a third factor of production lowers the productivity of labor and capital in the short run. ${ }^{11}$ Consequently, full-employment output will be less, but the amount of labor employment consistent with that reduced output will be the same as before the increase in the price of energy.

Movements in supply and demand over time Equilibrium is defined after the supply and demand functions have been specified; it is simply the combination of price level and output that equates supply and demand. Implicit in this equilibrium, however, is the assumption of equilibrium in both the money market, given the stock of money, and the labor market, given the nominal wage. Neither supply nor demand remains stationary, and it is the path of output and the price level traced out through time that concerns the economic analyst.

Research results support the notion that shifts of aggregate demand over time are dominated by the rate of monetary expansion. While other factors lead to changes in aggregate demand as well, they are assumed to be captured in the velocity term in this simple model.

Aggregate supply tends to shift because of changes in factors that were assumed constant in the construction of figures 1 and 2. In other words, changes in nominal wages, the price of energy, the size of the labor force, and productivity will shift aggregate supply over time. Underlying productivity changes are trends in the capital stock and technology.

\section{Supply and Demand Analusis of the \\ Tirst Half of 1979}

This framework of analysis is now applied to the economic experience of the first half of 1979 , from IV $/ 78$ to $\mathrm{II} / 79 .{ }^{12}$

Defining a reference point - In figure 3 , point $A$ represents the actual position of the economy in the fourth quarter of 1978. It is assumed that this is a

11See Rasche and Tatom, "Effects of the New Energy Regime."

12Preliminary data have been released for the third quarter of 1979 , but because these first estimates are subject to revision, the analysis focuses on the period from IV $/ 78$ to II/79,

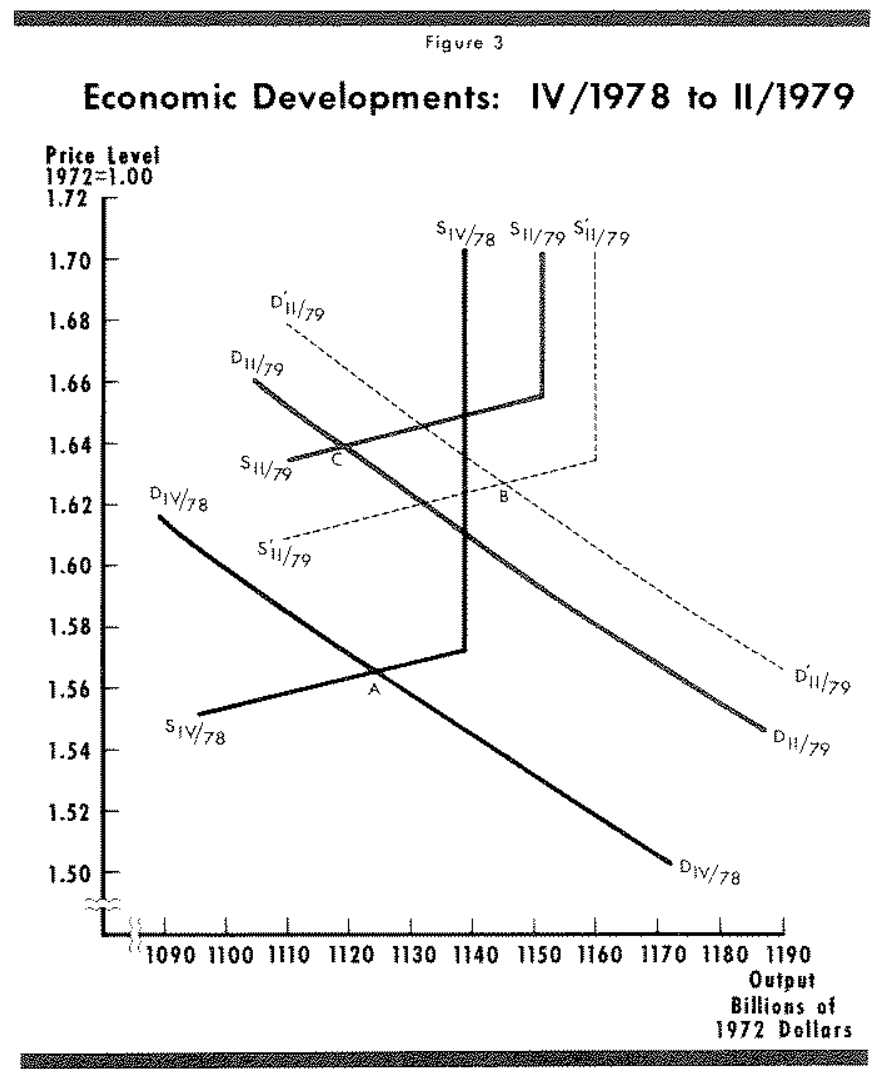

point of equilibrium of supply and demand and that this equilibrium occurs at less than full-employment output. ${ }^{13}$

Point $B$ represents the position the economy would have reached in the second quarter of 1979 had both aggregate supply and demand grown in line with past trends. The growth rate for aggregate supply is as sumed to be a 3.8 percent amnual rate of increase. Aggregate demand is drawn commensurate with a continuation of the 8 percent rate of increase in money which prevailed from $\mathrm{III} / 76$ to $\mathrm{LI} / 78,{ }^{14}$ Point B serves as a useful point of reference in analyzing what actually happened between IV/78 and II/79 because it represents a continuation of past trends. Departures from point $B$ can be accounted for by factors influencing supply and/or demand.

Where the economy was in $I / 79$ and why - The economy did not move to point $\mathrm{B}$ in the second quarter of 1979. Rather, it moved to point $\mathrm{G}$, a point of

1.3 In reality, however, the level of full-employment output is not clearly defined, and some analysts believe the economy was operating at full employment in the fourth quarter of 1978. See, for example, lhillip Cagan, "The Reduction of Inflation by Slack Demand," in William Fellner, Project Director, Confemporary Economic Problems 1978 (Washington, D.C.: American Enterprise Institute, 1978), pp. 13 45 .

14These rates of change are quoted for money defined to include ATS accounts and New York NOW accounts. 


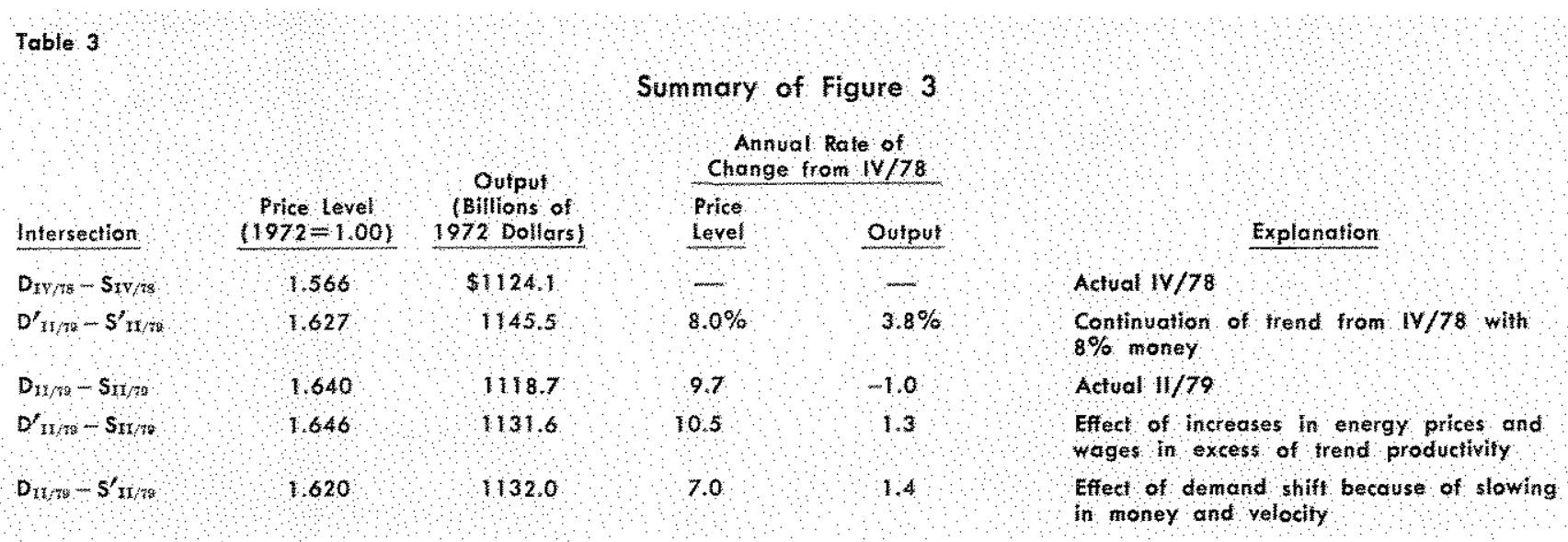

higher price and lower output levels than at point B. Both supply and demand shifted differently than indicated by a continuation of trends that prevailed in late 1978 .

First of all, demand did not shift to the extent indicated by reference point $B$. One reason for this was that the growth in the money stock slowed dramatically beginning in November 1978. However, it accelerated again in the second quarter of 1979 and, on balance, showed a 6 percent annual rate of increase from III $/ 78$ to $11 / 79$. Nonetheless, the difference between the actual and the implied shifts in aggregate demand is greater than can be explained solely by the slowing in monetary growth. Velocity growth also slowed, or, in terms of the demand for money, there was an apparent increase in the quantity of money demanded at each level of nominal GNP during this period. Variations in velocity about its trend are not uncommon for short periods. Although the effects of shortterm fuctuations are only temporary, the pace of activity can be affected by variations as brief as two quarters. Even if aggregate supply had shifted in accordance with its trend, output would have been affected by the slowing of the money stock and velocity.

Figure 3 also shows that aggregate supply did not shift as indicated by reference point $B$. Supply, instead of shifting to $S_{11 / 79}^{\prime}$, shifted to $S_{\mathrm{IY/75} .}$. Two factors contributed to this: (1) nominal wages increased 8.9 percent in excess of trend productivity instead of 8.0 percent as implied by trend factors, and (2) the relative price of energy increased at a 30 percent anmual rate.

The information contained in figure 3 is summarized in table 3 . Using hypothetical point $B$ as a reference, shifts in both supply and demand contributed to the decline in output from IV/78 to II/79. For this short period, however, supply conditions were primarily responsible for an increase in the price level in excess of that suggested by the continuation of trend.

\section{Economic Otulook}

Given the explanation of how the economy moved to a higher price level and a lower output level in

Toble 4

\section{Assumptions Underlying Figure 4 \\ (Annual Rates of Change)}

\begin{tabular}{|c|c|c|c|c|c|c|c|c|c|c|c|c|}
\hline & \multicolumn{6}{|c|}{ AGGREGATE DEMAND } & \multicolumn{6}{|c|}{ AGGREGATE SUPPLY } \\
\hline & \multicolumn{3}{|c|}{$6 \%$ Money Growth } & \multicolumn{3}{|c|}{$8 \%$ Money Growh } & \multicolumn{3}{|c|}{$6 \%$ Money Growh } & \multicolumn{3}{|c|}{$8 \%$ Money Growh } \\
\hline & Money & Yelocity & GNP & Money & Velocify & QNP & $\begin{array}{l}\text { Nominal } \\
\text { Wages }\end{array}$ & $\begin{array}{l}\text { Energy } \\
\text { Brices }\end{array}$ & $\begin{array}{c}\text { Fult. } \\
\text { mploy } \\
\text { ment } \\
\text { Oufpul }\end{array}$ & $\begin{array}{c}\text { Nominol } \\
\text { Wrges }\end{array}$ & $\begin{array}{l}\text { Energy } \\
\text { Prices }\end{array}$ & $\begin{array}{l}\text { Full- } \\
\text { employ- } \\
\text { ment } \\
\text { Output* }\end{array}$ \\
\hline $11 / 79.1 V / 79$ & $8.5 \%$ & $3.8 \%$ & $12.6 \%$ & $9.5 \%$ & $3.8 \%$ & $13.6 \%$ & $9.5 \%$ & $54.8 \%$ & $3.8 \%$ & $10.1 \%$ & $54.8 \%$ & $3.8 \%$ \\
\hline $17 / 79-11 / 80$ & 6.0 & 3.8 & 10.1 & 8.0 & 3.8 & 12.2 & 8.5 & 15.9 & 3.8 & 9.8 & 15.9 & 3.8 \\
\hline $11 / 80 \pi \mathrm{IV} / 80$ & 60 & 3.8 & 10.1 & 8.0 & 3.8 & 12.1 & 7.5 & 15.0 & 3.8 & 9.5 & 15.0 & 3.8 \\
\hline
\end{tabular}

*Growth rate if relative price of energy were constant. 


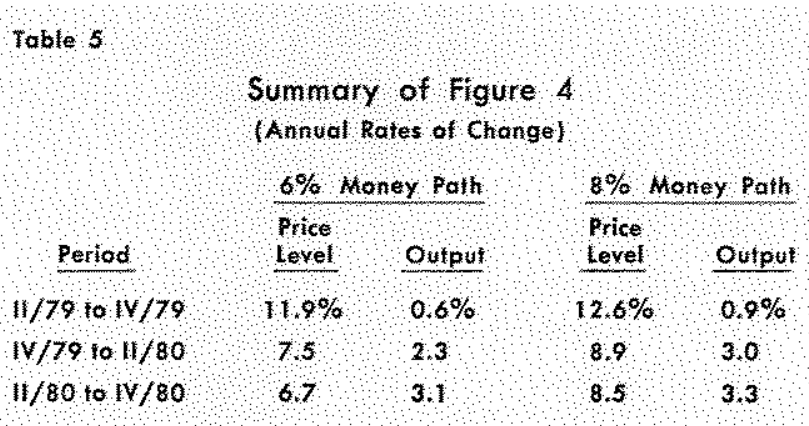

the first half of 1979 , what are the implications for the future? The movement in recent months of those key variables that influence aggregate supply and demand in the short run is a primary consideration.

Recent Developments -- The short-run focus of this analytical framework is on changes in the money stock, nominal wages, and the price of energy. Other factors are at work, but for the most part these factors change only gradually from past trends.

The variable for which the most current informa. tion is available is the money stock. Since the second quarter of $1979, \mathrm{M} 1$ (without adjustments for ATS and NOW accounts) has increased at a 10 percent annual rate. With an allowance for these checkable deposits, the increase has probably been in excess of 11 percent. This rate of increase is one of the most rapid for periods of similar length in the postwar period.

The other development of note is the continuing increase in the price of energy as the effect of OPEC cartel actions and the gradual decontrol of domestic prices work their way through the price structure. Since the second quarter of 1979 , the nominal price of energy has risen at a 73 percent annual rate, which indicates that further adjustments in aggregate supply are forthcoming.

The last factor, nominal wages, has increased at a moderate rate of 8.5 percent since the second quarter. If rapid monetary growth continues and further stimulates aggregate demand, there is some question whether rates of increase in nominal wages will continue in the 8 percent to 9 percent range.

Policy Options - Given this framework of analysis and some indication of more recent developments, the impact of alternative policy scenarios can be investigated. Taking the rapid growth in money in the third quarter of 1979 as a starting point, two policy scenarios are considered: (1) the rate of money growth will be reduced to 8 percent beginning in the fourth quarter of 1979 and held steady at that rate through 1980 ,

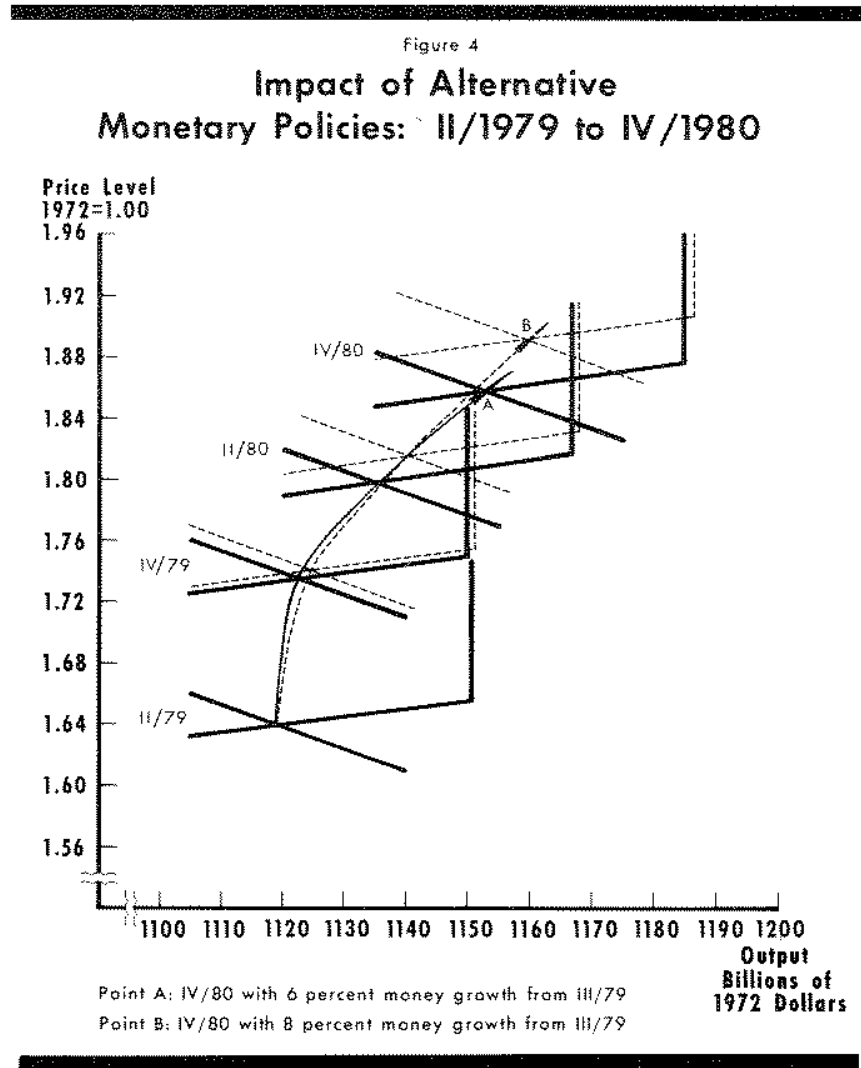

and (2) beginning in the fourth quarter of 1979 , the rate of money growth will be slowed to 6 percent. Both scenarios are based on the same pattern of energy prices, but the rate of change in nominal wages is assumed to be related to the rate of increase in the money stock. ${ }^{15}$ The excess by which nominal wages increase over trend productivity is assumed to approach the rate of monetary growth by the second half of $1980 .^{16}$ The assumptions underlying these policy scenarios are summarized in table 4 .

Figure 4 and table 5 summarize the results. The bottom pair of supply and demand curves shows the position of the economy in the second quarter of 1979. The succession of supply and demand intersections for every other quarter through the fourth quarter of 1980 shows two paths corresponding to the two monetary policy scenarios. The solid lines represent the 6 percent case while the dashed lines represent the 8 percent case. Full-employment output is projected to change only slightly from II/79 to IV $/ 79$, then resume

15This assumption is quite arbitrary, but does refect preliminary research into the relationship between nominal wages and money.

16Relative to accumulated empirical evidence, this speed of adjustment is probably too fast. Consequently, the scenarios should be interpreted as optimistic and perhaps in line with the rational expectations literature. 
its increase from IV/79 to IV/80. This pattern reflects the assumption that the rapid acceleration in energy prices will slow by the beginning of 1980 .

The path for 6 percent money growth is shown by connecting the intersections of the solid lines, and for 8 percent by connecting the intersecting dashed lines. Because of the assumed interdependence over time of aggregate supply and demand (reflecting the assumption that wages are influenced by money growth), the two paths appear to be quite close together. However, by the second half of 1980 , the price level would be rising more rapidly along the 8 percent path than along the 6 percent path, even though the rates of output growth would be similar.

The course of the economy is still being influenced by the rapid acceleration in the price of energy which began in early 1979. This factor is largely responsible for the rapid upward shifts in aggregate supply into 1980. Given this assumed pattern of increase in energy prices, the role for monetary policy is to follow a moderate course, avoiding extremes of stimulus or restraint. Price level increases attributable to energy prices cannot be reduced by restrictive monetary ac- tions. On the other hand, stimulative actions to restore output to its original growth path (a failure to recognize the impact of energy prices on full-employ. ment output) will lead to sharply accelerating prices.

\section{Summary and Conclusions}

The economic slowdown in the first half of 1979 can be attributed to shifts in aggregate supply and demand. Aggregate demand slowed because both money growth and velocity dropped below previous trends. Aggregate supply, on the other hand, was affected by energy prices and a rise in nominal wages well in excess of trend productivity.

An examination of the near-term economic outlook within the framework of supply and demand indicates that energy prices will continue to have adverse effects on aggregate supply through 1979. The rapid growth of money in the third quarter of 1979 will tend to dampen the decline in output, but eventually will result in further upward price movements. Assuming that energy prices moderate in the near future, the rate of inflation should again reflect more closely the growth rate of money.

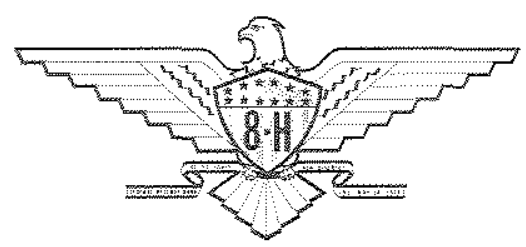

